\title{
Keefektifan Ekstrak Air Daun Binahong (Anredera cordifolia (Ten.) Steenis) dalam Menekan Pertumbuhan Koloni dan Perkecambahan Konidia Jamur Colletotrichum capsici Penyebab Penyakit Antraknos pada Cabai
}

\author{
Endah Yulia ${ }^{1 *}$, Fitri Widiantini ${ }^{1}$, Andang Purnama ${ }^{1}$ dan Ida Nurhelawati ${ }^{2}$ \\ ${ }^{1}$ Departemen Hama dan Penyakit Tumbuhan, Fakultas Pertanian, Universitas Padjadjaran \\ ${ }^{2}$ Alumni Departemen HPT, Fakultas Pertanian, Universitas Padjadjaran \\ Jl. Raya Bandung-Sumedang KM 21 Jatinangor 40600 \\ *Alamat korespondensi: endah.yulia@unpad.ac.id
}

\begin{abstract}
Effectiveness of Aqueous Extract of Binahong (Anredera cordifolia (Ten.) Steenis) Leaves in Suppressing Colony Growth and Conidia Germination of Colletotrichum capsici the Causal Agents of Anthracnose Disease on Chili
\end{abstract}

\begin{abstract}
Anthracnose disease caused by the fungus Colletotrichum spp. is a major disease in chili. Several studies have reported the effectiveness of some plant extracts in suppressing the growth of this pathogen and in controlling the disease. Binahong (Anredera cordifolia) plant has been widely studied and used in traditional medicine in the field of human health as well as antimicrobial on plant pathogens. This study was aimed to test the effectiveness of the aqueous extract of binahong leaves to suppress the colony growth and conidia germination of the fungus $C$. capsici. The concentration of binahong aqueous extract tested were $6.25 \%, 8.84 \%, 12.5 \%, 17.7 \%$ and $25 \%$. Results showed binahong aqueous extract at low concentration of $6.25 \%$ was able to suppress the growth of fungal mycelium of C. capsici up to $66.88 \%$ compared to the lower effectiveness of higher tested concentrations. The aqueous extract of binahong leaves at this low concentration also tended to suppress the germination of conidia of the fungus C. capsici in in higher tested concentrations.
\end{abstract}

Keywords: Colletotrichum capsici, Aqueous extract, Anredera cordifolia

\begin{abstract}
ABSTRAK
Penyakit Antraknos yang disebabkan oleh jamur Colletotrichum spp. merupakan penyakit utama pada tanaman cabai. Beberapa penelitian melaporkan keefektifan beberapa ekstrak tanaman dalam menekan pertumbuhan patogen Colletotrichum spp. dan dalam mengendalikan penyakit Antraknos ini. Tanaman binahong sudah banyak diteliti dan digunakan dalam pengobatan tradisional di bidang kesehatan manusia maupun sebagai antimikroba patogen tanaman. Penelitian menggunakan metode eksperimen Rancangan Acak Lengkap (RAL) dengan pengujian keefektifan ekstrak air daun binahong terhadap pertumbuhan koloni dan perkecambahan konidia jamur C. capsici. Konsentrasi ekstrak air binahong yang diuji adalah 6,25\%, 8,84\%, 12,5\%, 17,7\% dan 25\%. Hasil menunjukkan ekstrak air binahong pada konsentrasi rendah 6,25\% mampu menekan pertumbuhan miselium jamur C. capsici sampai 66,88\% dibandingkan keefektifan yang lebih rendah pada konsentrasi yang lebih tinggi. Ekstrak air binahong pada konsentrasi rendah tersebut juga cenderung menekan perkecambahan konidia jamur C. capsici.
\end{abstract}

Kata Kunci: Colletotrichum capsici, Ekstrak air, Anredera cordifolia 


\section{PENDAHULUAN}

Cabai (Capsicum annuum L.) merupakan salah satu komoditas penting di Indonesia. Namun tingkat produksi cabai ini masih lebih rendah bila dibandingkan dengan potensi produksi cabai yang dapat dicapai (Agustin dkk., 2010). Rendahnya produktivitas cabai tersebut salah satunya disebabkan oleh adanya gangguan dari Organisme Pengganggu Tanaman (OPT). Salah satu OPT penting dalam budidaya tanaman cabai yaitu jamur Colletotrichum spp. yang merupakan penyebab penyakit antraknos. Penyakit ini disebabkan oleh beberapa spesies jamur genus Colletotrichum dengan enam spesies utama yaitu $C$. gloeosporioides, $C$. acutatum, C. capsici, C. coccodes, dan C. dematium (Kim et al., 1999 dalam Syukur dkk., 2009). Patogen yang paling banyak menyebabkan penyakit antraknos di Indonesia yaitu C. gloeosporioides dan C. capsici (Suryaningsih et al., 1996 dalam Syukur dkk., 2009). Serangan penyakit ini dilaporkan dapat menyebabkan terjadinya kehilangan hasil mencapai $50 \%$ pada tanaman cabai (Suryaningsih \& Suhardi, 1993 dalam Sulaksono dkk., 2002). Bahkan dilaporkan jika pengendalian terhadap penyakit antraknos ini kurang tepat, kehilangan hasil buah cabai dapat mencapai 100\% (Gunawan, 2006).

Pada umumnya penyakit antraknos ini dikendalikan dengan menggunakan fungisida sintetik yang intensif. Penggunaan fungsida dilakukan dengan penggunaan dosis yang tinggi serta interval aplikasi yang bisa mencapai 3-4 kali dalam seminggu sehingga dapat menimbulkan dampak negatif terhadap lingkungan (Duriat, 2007). Untuk mencegah hal tersebut, penggunaan ekstrak tumbuhan sebagai pestisida nabati dapat dijadikan sebagai alternatif pengendalian penyakit. Penggunaan pestisida nabati atau ekstrak tanaman untuk mengendalikan penyakit atau menekan Data hasil penelitian diolah secara statistik dengan menggunakan program SPSS Versi 17. Analisis data dilakukan dengan menggunakan ANOVA dan Uji Lanjut Duncan pada taraf nyata 5\% untuk membandingkan perlakuan (Gomez \& Gomez, 2007).pertumbuhan patogen pada beberapa jenis tanaman telah banyak dilaporkan. Cowan (1999) dalam Dellavalle et al. (2010) menyatakan bahwa beberapa ekstrak tanaman telah diuji sebagai antimikroba dan memberikan hasil yang baik dan efektif dalam menekan patogen tanaman maupun mikroorganisme lain. Beberapa ekstrak tanaman juga dilaporkan dapat mengendalikan $C$. capsici. Pestisida nabati yang berasal dari ekstrak daun widuri
(Calotropis sp.) dilaporkan efektif menghambat pertumbuhan miselium dan mengurangi produksi konidia C. capsici (Sulaksono et al., 2002). Selain itu, ekstrak daun mengkudu juga dilaporkan dapat menghambat pertumbuhan koloni C. capsici (Rani dkk., 2013).

Tanaman binahong (Anredera cordifolia (Ten.) Stennis) merupakan salah satu spesies dari famili Basellaceae yang banyak digunakan dalam pengobatan di bidang kesehatan manusia dan juga sebagai antimikroba patogen tanaman (Amertha et al., 2012; Dewabrata, 2012; Djamil et al., 2012; Ekaviantiwi dkk., 2013; Miladiyah \& Prabowo, 2012; Wardhani \& Sulistyani, 2012). Di China, Korea dan Taiwan tanaman binahong telah diketahui dapat menyembuhkan penyakit dan telah dikonsumsi selama lebih dari ratusan tahun (Fei, 2009 dalam Astuti et al., 2011). Tanaman ini biasa digunakan untuk mengobati luka, menghaluskan kulit, menghilangkan sakit badan, meningkatkan stamina tubuh, serta sebagai antioksidan. Menurut Setiaji (2009) yang dikutip oleh Darsana (2012), A. cordifolia dapat digunakan sebagai obat antibakteri.

Kemampuan ekstrak tanaman dalam menekan pertumbuhan patogen umumnya disebabkan oleh senyawa metabolit yang dikandungnya. Tanaman dalam metabolismenya selain menghasilkan senyawa primer juga menghasilkan senyawa sekunder seperti fenol, alkaloid, terpenoid, dan senyawa lainnya (Rukmana \& Oesman, 2002). Geissman (1963) dalam Cowan (1999) menyatakan bahwa tanaman memiliki kemampuan untuk mensintesis suatu zat aromatik yang sebagian besar merupakan fenol. Beberapa senyawa bioaktif seperti flavonoid, saponin, triterpenoid, komarin dan asam fenolat dilaporkan terdapat di dalam tanaman binahong (Astuti et al., 2011; Djamil et al., 2012). Tujuan dari penelitian ini adalah untuk mengetahui keefektifan ekstrak air daun binahong dalam menekan pertumbuhan $C$. capsici.

\section{BAHAN DAN METODE}

Penelitian dilaksanakan di Laboratorium Fitopatologi, Departemen Hama dan penyakit Tumbuhan, Fakultas Pertanian, Universitas Padjadjaran. Penelitian menggunakan metode eksperimen Rancangan Acak Lengkap (RAL) dengan pengujian keefektifan ekstrak air daun binahong terhadap pertumbuhan koloni dan perkecambahan konidia jamur C. capsici. Konsentrasi ekstrak air 
binahong yang diuji adalah 6,25\%, 8,84\%, 12,5\%, $17,7 \%$ dan $25 \%$.

\section{Isolasi dan Penyiapan Biakan Murni Jamur Colletotrichum capsici}

Jamur C. capsici diisolasi dari buah cabai yang menunjukkan gejala antraknos. Bagian antara yang sehat dan yang bergejala dipotong dari permukaan buah (Agrios, 2005). Potongan-potongan kecil ini dicelupkan beberapa detik ke dalam larutan alkohol 70\% yang kemudian direndam pada larutan sodium hypoklorit $1 \%$ selama lima menit. Jaringan yang sudah disterilkan ini dicuci satu kali dengan menggunakan akuades steril yang kemudian diletakkan pada media tumbuh pada Petri dish dan diinkubasikan pada suhu ruang $\left( \pm 28^{\circ} \mathrm{C}\right)$. Miselium yang tumbuh kemudian dipindahkan ke media Potato Dextrose Agar (PDA) yang baru sebagai biakan murni. Isolat yang telah murni digunakan pada percobaan kurang lebih tujuh hari setelah inkubasi. Media yang digunakan untuk perbanyakan dan pengujian adalah media PDA dan water agar (WA).

\section{Ekstraksi Daun Binahong}

Bahan tanaman binahong untuk ekstrak diperoleh dari daerah sekitar wilayah Bandung. Ekstrak tanaman disiapkan dengan cara memblender daun segar dalam akuades steril menggunakan blender sampai halus. Penyaringan dilakukan secara bertingkat dengan menggunakan kain muslin, kertas saring, kertas saring Whatman No.1, dan kemudian disterilkan dengan menggunakan saringan millipore (ukuran 0,2 $\mu \mathrm{m}$ ). Ekstrak yang dihasilkan langsung digunakan untuk pengujian.

\section{Uji Penghambatan Ekstrak Air Daun Binahong} terhadap Pertumbuhan Jamur Colletotrichum capsici

Uji penghambatan pertumbuhan $C$. capsici. dilakukan untuk mengetahui ukuran diameter koloni pada media pengujian yang telah dicampur ekstrak air daun binahong. Pengujian penghambatan pertumbuhan ini menggunakan metode poison food (Dhingra \& Sinclair, 1985). Ekstrak air daun binhong dengan konsentrasi tertentu dicampurkan (1 $\mathrm{ml}: 9$ ml) pada Petri dish steril dengan media PDA yang telah disterilisasi kemudian digoyang-goyangkan sehingga media PDA dan ekstrak perlakuan bercampur merata. Sebagai kontrol digunakan akuades steril yang dicampurkan pada media PDA.
Jamur C. capsici. yang telah dimurnikan diambil dengan pembor gabus yang berukuran $5 \mathrm{~mm}$ dan diletakkan pada bagian tengah Petri dish. Pengamatan terhadap diameter koloni jamur yang diukur dilakukan pada interval waktu 24 jam sampai perlakuan kontrol mencapai diameter maksimal (pertumbuhannya memenuhi permukaan Petri dish).

\section{Uji Penghambatan Perkecambahan Konidia Colletotrichum capsici}

Pengujian penghambatan perkecambahan konidia $C$. capsici dilakukan dengan terlebih dahulu menyiapkan suspensi konidia yang diencerkan dengan menambahkan akuades steril untuk mendapatkan suspensi konidia ( $1 \times 10^{5}$ konidia/ml). Penghambatan perkecambahan konidia dilakukan dengan melakukan pencampuran (perbandingan 1 : 1) suspensi konidia ( $\left.1 \times 10^{6} \mathrm{konidia} / \mathrm{ml}\right)$ dengan $3 \%$ WA pada suhu $45^{\circ} \mathrm{C}$ (Yulia et al., 2006). Hasil campuran dituangkan ke dalam Petri dish sebanyak $10 \mathrm{ml}$. Setelah kering, agar-konidia dipotong dengan ukuran diameter $5 \mathrm{~mm}$ menggunakan pembor gabus. Kemudian potongan agar konidia ditempatkan pada objek gelas steril. Ekstrak yang menunjukkan penekanan pertumbuhan jamur $C$. capsici. yang paling baik diaplikasikan pada permukaan agarkonidia dengan volume $10 \mu \mathrm{l}$. Pada kontrol, sebagai pengganti perlakuan digunakan akuades steril. Objek gelas dengan perlakuan agar-konidia disimpan pada boks steril dan diinkubasi selama 7 jam pada suhu ruang. Perkecambahan konidia diamati dengan menggunakan mikroskop cahaya pada perbesaran 400x.

\section{HASIL DAN PEMBAHASAN}

\section{Isolat Jamur Colletotrichum capsici}

Cabai merah yang menunjukkan gejala penyakit antraknos diperoleh dari areal pertanaman cabai petani di daerah Lembang, Bandung Barat. Gejala penyakit antraknos pada buah cabai dan biakan murni C. capsici. hasil isolasi disajikan pada Gambar 1. Penyakit antraknos telah menjadi penyakit utama di pertanaman cabai termasuk di daerah Lembang dan dilaporkan sebagai penyebab rendahnya produksi cabai di Indonesia (Hasyim et al., 2014). 

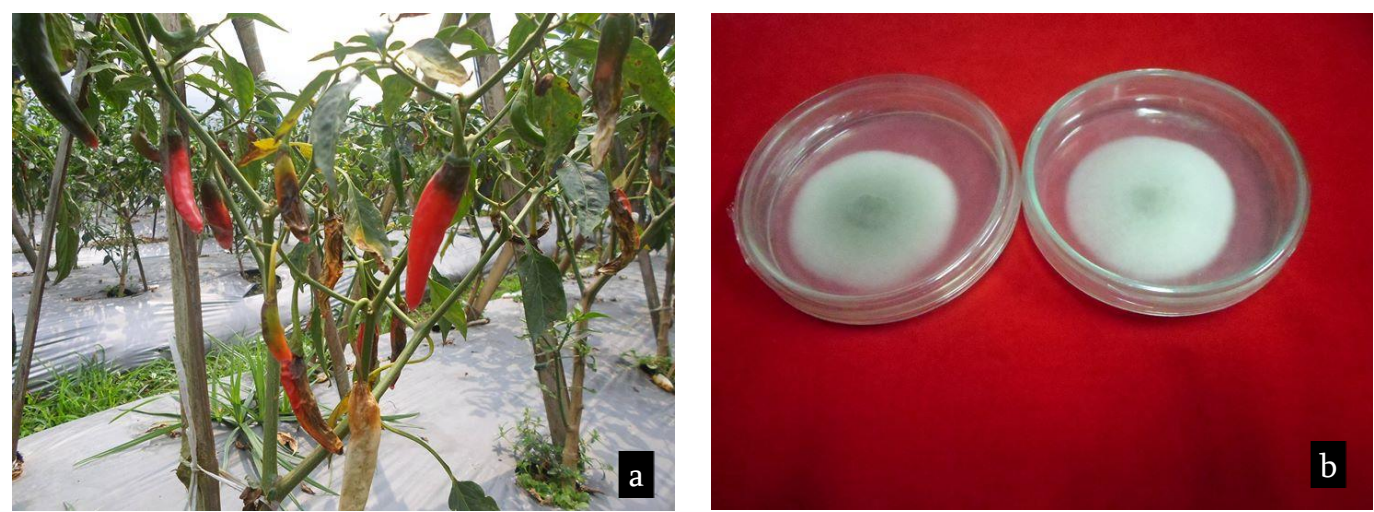

Gambar 1. Penyakit Antraknos pada cabai. (a) Cabai yang terserang penyakit Antraknos di areal pertanaman cabai di daerah Lembang. (b) Biakan murni Colletotrichum capsici.

Pengaruh Ekstrak Air Daun Binahong terhadap Pertumbuhan Miselium Jamur Colletotrichum capsici Hasil pengujian menunjukkan efek penekanan ekstrak air binahong terhadap pertumbuhan miselium jamur C. capsici (Gambar 2; Tabel 1). Secara umum, semua konsentrasi ekstrak air binahong dapat menghambat pertumbuhan miselium jamur C. capsici. Penghambatan pertumbuhan miselium jamur tertinggi ditunjukkan oleh ekstrak air binahong pada konsentrasi terendah (6,25\%) dimana pada semua konsentrasi yang lebih tinggi dan bahkan pada konsentrasi yang tertinggi (25\%) penghambatan pertumbuhan miselium jamur cenderung rendah dan tidak berbeda nyata dengan perlakuan kontrol.
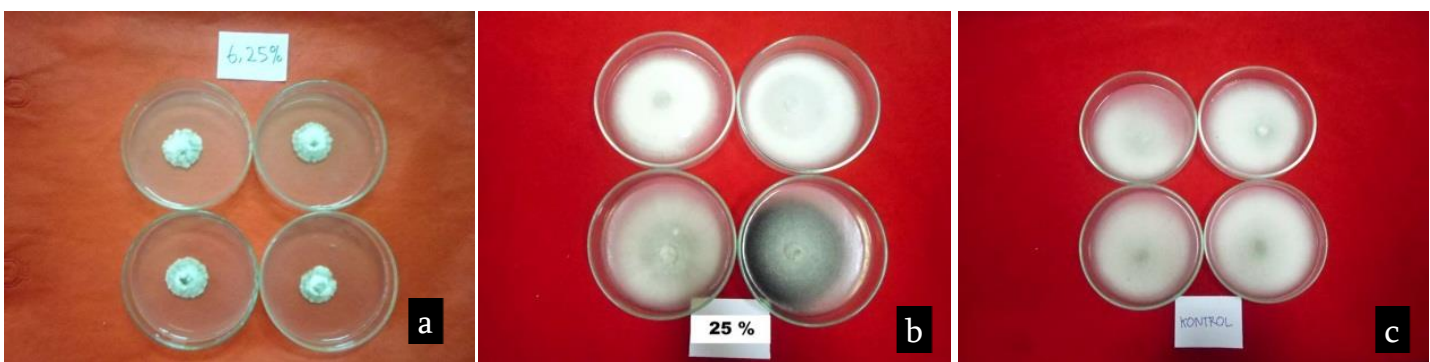

Gambar 2. Pengujian penekanan pertumbuhan miselium jamur C. capsici. (a) Perlakuan dengan ekstrak air binahong konsentrasi 6,25\%. (b) Perlakuan dengan ekstrak air binahong konsentrasi 25\%. (c) Perlakuan kontrol.

Tabel 1. Penghambatan pertumbuhan miselium jamur C. capsici oleh ekstrak air daun binahong.

\begin{tabular}{lcc}
\hline \multicolumn{1}{c}{ Perlakuan } & Diameter koloni $(\mathrm{cm})$ & Penghambatan $(\%)$ \\
\hline 6,25\% ekstrak air daun binahong & $2,98 \mathrm{a}$ & 66,88 \\
$8,84 \%$ ekstrak air daun binahong & $8,75 \mathrm{~b}$ & 2,78 \\
12,5\% ekstrak air daun binahong & $8,68 \mathrm{~b}$ & 3,56 \\
17,7\% ekstrak air daun binahong & $8,78 \mathrm{~b}$ & 2,44 \\
25\% ekstrak air daun binahong & $8,65 \mathrm{~b}$ & 3,89 \\
Kontrol (tanpa perlakuan) & $9,00 \mathrm{~b}$ & - \\
\hline
\end{tabular}

Keterangan: Huruf yang sama pada satu kolom dalam tabel menunjukkan data tidak berbeda nyata dengan kontrol berdasarkan Uji Jarak Berganda Duncan 5\%.

Dari hasil di atas dapat dilihat adanya kecenderungan bahwa ekstrak air binahong pada konsentrasi yang tinggi justru cenderung menstimulasi pertumbuhan jamur C. capsici.
Fenomena kemampuan ekstrak tanaman yang lebih efektif pada konsentrasi rendah (komponen aktif tanaman bersifat antimikroba pada dosis yang rendah) ataupun cenderung meningkatkan 
pertumbuhan mikroorganisme pada konsentrasi yang lebih tinggi telah dilaporkan pada penelitianpenelitian sebelumnya (Handajani \& Purwoko, 2008; Johnny et al., 2011; Yulia et al., 2006).

Pada konsentrasi terendah (6,25\%) dengan penghambatan tertinggi ini, koloni jamur $C$. capsici tumbuh tidak normal dimana pertumbuhan koloni sangat lambat, tidak menyebar atau bertumpuk dibandingkan dengan pertumbuhan koloni yang normal pada perlakuan kontrol. Penghambatan dan perubahan pertumbuhan miselium jamur C. capsici ini diperkirakan karena kandungan senyawa metabolit sekunder yang dimiliki oleh binahong. Tanaman binahong diketahui memiliki beberap senyawa yang berperan sebagai antimikroba seperti alkaloid, flavonoid, saponin, triterpenoid, dan komarin (Astuti et al., 2011; Djamil et al., 2012). Sementara itu pada konsentrasi yang lebih tinggi, koloni jamur pada lebih tipis. Dalam kondisi terakhir, kemungkinan ekstrak air binahong bersifat fungistatik daripada fungisidal.

\section{Pengaruh Ekstrak Air Daun Binahong terhadap Perkecambahan Konidia Jamur C. capsici}

Hasil percobaan ekstrak air daun binahong terhadap perkecambahan konidia jamur C. capsici disajikan pada Tabel 2. Hasil menunjukkan bahwa ekstrak air daun binahong pada semua konsentrasi yang diuji tidak berbeda nyata dengan perlakuan kontrol dalam menghambat perkecambahan konidia jamur C. capsici. Bahkan pada perlakuan dengan konsentrasi ektrak air daun binahong tertinggi, perkecambahan konidia tinggi daripada perlakuan kontrol. Dalam hal perkecambahan konidia jamur, ada kecenderungan juga bahwa pada konsentrasi yang rendah ekstrak air daun binahong ini lebih menekan perkecambahan konidia jamur dibandingkan dengan ekstrak air daun binahong pada konsentrasi yang tinggi.

Tabel 2. Penghambatan perkecambahan konidia jamur C. capsici oleh ekstrak air daun binahong.

\begin{tabular}{ccc}
\hline \multicolumn{1}{c}{ Perlakuan } & Konidia berkecambah (\%) & $\begin{array}{c}\text { Penghambatan perkecambahan konidia } \\
(\%)\end{array}$ \\
\hline 6,25\% ekstrak air daun binahong & $83,41 \mathrm{a}$ & 5,63 \\
$8,84 \%$ ekstrak air daun binahong & $84,28 \mathrm{a}$ & 4,65 \\
$12,5 \%$ ekstrak air daun binahong & $88,10 \mathrm{a}$ & 0,34 \\
$17,7 \%$ ekstrak air daun binahong & $88,96 \mathrm{a}$ & 0 \\
$25 \%$ ekstrak air daun binahong & $93,98 \mathrm{a}$ & 0 \\
Kontrol (tanpa perlakuan) & $88,39 \mathrm{a}$ & - \\
\hline
\end{tabular}

Keterangan: Huruf yang sama pada satu kolom dalam tabel menunjukkan data tidak berbeda nyata dengan kontrol berdasarkan Uji Jarak Berganda Duncan 5\%.

Kejadian perkecambahan konidia jamur yang lebih tinggi pada konsentrasi ekstrak yang lebih tinggi dapat disebabkan oleh beberapa faktor yang memengaruhi perkecambahan konidia dimana pada konsentrasi yang tinggi perkecambahan konidia jamur bahkan terstimulasi (Fiori et al., 2000). Hal ini terjadi diperkirakan berkaitan dengan karakteristik ekstrak yang tidak yang tidak bersifat fungisidal, ataupun berkaitan dengan jumlah kandungan, cara kerja dan jenis senyawa kimia pada tanaman binahong yang terekstrak dan berperan sebagai senyawa antimikroba. Penggunaan pelarut air yang digunakan pada penelitian ini juga mungkin telah memengaruhi senyawa yang didapatkan yang masih beragam. Meskipun secara kuantitatif perkecambahan konidia ini cenderung tidak dipengaruhi secara signifikan oleh penggunaan ekstrak air daun binahong, secara kualitatif ada pengaruh yang berbeda pada keadaan konidia yang berkecambah pada perlakuan ekstrak air daun binahong. Terdeteksi beberapa perubahan atau perbedaan morfologi konidia yang berkecambah pada perlakuan ekstrak air daun binahong dibandingkan dengan konidia yang berkecambah pada perlakuan kontrol.

\section{SIMPULAN}

Ekstrak air daun binahong pada konsentrasi yang rendah $(6,25 \%)$ mampu menghambat pertumbuhan miselium jamur $C$. capsici dengan penghambatan sebesar $66,88 \%$ dibandingkan dengan keefektifan ekstrak yang lebih rendah pada konsentrasi yang lebih tinggi. Pada konsentrasi rendah ini juga ekstrak air daun binahong dapat menghambat perkecambahan konidia jamur $C$. capsici dengan presentase penghambatan sebesar $5,63 \%$ dengan kecenderungan tidak terjadi penghambatan perkecambahan konidia pada konsentrasi yang lebih tinggi yang diuji. 


\section{DAFTAR PUSTAKA}

Agrios, NG. 2005. Plant Pathology. $5^{\text {th }}$ ed. Academic Press. San Diego.

Agustin, W, S Ilyas, SW Budi, I Anas, dan FC Suwarno. 2010. Inokulasi Fungi Mikoriza Arbuskular (FMA) dan pemupukan P untuk meningkatkan hasil dan mutu benih cabai (Capsicum annuum L.). J. Agron Indonesia. 38(3): 218-224.

Amertha, IBPM, S Soeliongan, and C Kountul. 2012. In vitro inhibition zone test of binahong (Anrodera cordifolia) towards Stahphylococcus aureus, Enterococcus faecalis, Escherichia coli, and Pseudomonas aeruginosa. Indonesia Journal of Biomedical Science. 6(1): 30-34.

Astuti, SM, M Sakinah, R Andayani, and A Risch. 2011. Determination of saponin compound from Anredera cordifolia (Ten) Steenis plant (binahong) to potential treatment for several diseases. Journal of Agricultural Science. 3(4): 224-232.

Cowan, MM. 1999. Plant product as antimicrobial agents. Clinical Microbiology Reviews. 12(4): 564-582.

Darsana, IGO. 2012. Potensi daun binahong (Anredera cordifolia (Tenore) Steenis) dalam menghambat pertumbuhan bakteri Escherichia coli secara in vitro. Indonesia Medicus veterinus. 1(3): 337-351.

Dellavalle, PD, A Cabrera, D Alem, P Larranaga, F Ferreria, and MD Rizza. 2011. Antifungal activity of medicinal plant extract againts phytopathogenic fungus Alternaria spp. Chilean Journal of Agricultural Research. 71(2): 232-239.

Dewabrata, D.P. 2012. Efektivitas Ekstrak Daun Binahong (Anredera cordifolia (Tenore) Steen) dalam Menghambat Pertumbuhan Jamur Fusarium oxysporum. Skripsi Fakultas Keguruan dan Ilmu Pendidikan, Universitas Jember. Tidak dipublikasikan.

Dhingra, OD, and JB Sinclair. 1985. Basic Plant Pathology Methods. CRC Press, Inc. Florida.

Djamil, R, PS Wahyudi, S Wahono, and M Hanafi. 2012. Antioxidant activity of flavonoid fron Anredera cordifolia (Ten) steenis leaves. International Research Journal of Pharmacy. 3(9): 241-243.

Duriat, AS, N Gunaeni, dan AW Wulandari. 2007. Penyakit Penting Tanaman Cabai dan
Pengendaliannya. Balai Penelitian Tanaman Sayuran. Lembang.

Ekaviantiwi, TA, E Fachriyah, and D Kusrini. 2013. Identifikasi asam fenolat dari ekstrak etanol daun binahong (Anredera cordifolia (Ten.) Stennis) dan uji aktivitas antioksidan. Chem. Info. 1(1): 283-293.

Fiori, ACG, KRF Schwan-Estrada, JR Stangarlin, JB Vida, CA Scapim, MES Cruz, and SF Pascholati. 2000. Antifungal activity of leaf extracts and essential oils of some medicinal plants against Didymella bryoniae. Journal of Phytopathology. 148(7-8): 483-487.

Gomez, KA, dan AA Gomez. 2007. Prosedur statistik untuk penelitian pertanian. Universitas Indonesia Press. Jakarta.

Gunawan, OS. 2006. Mikroba antagonis untuk pengendalian penyakit antraknos pada cabai merah. J. Hort. 16(2): 151-155.

Handajani, NS, dan T Purwoko. 2008. Aktivitas ekstrak rimpang lengkuas (Alpinia galanga) terhadap pertumbuhan jamur Aspergillus spp. penghasil aflatoksin dan Fusarium moniliforme. Biodiversitas. 9(3): 161-164.

Hasyim, A, W Setiawati, and R Sutarya. 2014. Screening for resistance to anthracnose caused by Colletotrichum acutatum in chili pepper. Advances in Agriculture \& Botanics International Journal of the Bioflux Society. 6(2): 104-118

Johnny, L, UK Yusuf, and R Nulit. 2011. Antifungal activity of selected plant leaves crude extracts against a pepper anthracnose fungus, Colletotrichum capsici (Sydow) Butler and Bisby (Ascomycota: Phyllachorales). African Journal of Biotechnology. 10(20): 4157-4165.

Miladiyah, I, and BR Prabowo. 2012. Ethanolic extract of Anredera cordifolia (Ten.) Steenis leaves improved wound healing in guinea pigs. Universa Medicina. 31(1): 4-11.

Rani, SEP, Efri, dan J Prasetyo. 2013. Pengaruh berbagai tingkat fraksi ekstrak daun mengkudu (Morinda citrifolia L.) terhadap pertumbuhan Colletotrichum capsici penyebab penyakit Antraknos pada cabai (Capsicum annum L.) secara in vitro. J. Agrotek Tropika. 1(1): 92-97.

Rukmana, R, dan YY Oesman. 2002. Nimba: Tanaman Penghasil Pestisida Nabati. Kanisius. Yogyakarta.

Sulaksono, P, Umrah, Ramadhani, PK Lamai, dan R Binangkari. 2002. Efek penghambatan ekstrak daun widuri (Calotropis sp.) 
terhadap jamur busuk buah cabai (Colletotrichum capsici). Jurnal Hama dan Penyakit Tumbuhan Tropika. 2(1): 20-25.

Syukur, M, S Sujiprihati, J Koswara, dan Widodo. 2009. Ketahanan terhadap antraknos yang disebabkan oleh Colletotrichum acutatum pada beberapa genotip cabai (Capsicum annuum L.) dan korelasinya dengan kandungan kapsaicin dan peroksidase. Jurnal Agron Indonesia. 37(3): 233-239.
Wardhani, LK, dan N Sulistyani. 2012. Uji aktivitas antibakteri ekstrak etil asetat daun binahong (Anredera scandens (L.) moq.) terhadap Shigella flexneri beserta profil kromatografi lapis tipis. Jurnal Ilmiah Kefarmasian. 2 (1): 1-16.

Yulia, E, WA Shipton, and RJ Coventry. 2006. Activity of some plant oil and extracts against Colletotrichum gloeosporioides. Plant Pathology Journal. 5(2): 253-257. 